УДК

\title{
СРАВНЕНИЕ ЭФФЕКТИВНОСТИ ПРОСТРАНСТВЕННО-ВРЕМЕННЫХ БЛОЧНЫХ И РЕШЕТЧАТЫХ КОДОВ В НАЗЕМНЫХ МІМО КАНАЛАХ МОБИЛЬНОЙ СПУТНИКОВОЙ СВЯЗИ*
}

\author{
к. Джинг ${ }^{1}$ и дж. ву² \\ ${ }^{1}$ Нанкинский университет аэронавтики и астронавтики, \\ Китай, Нанкин \\ ${ }^{2}$ ПАНДА электроникс груп, \\ Китай, Нанкин
}

\begin{abstract}
Аннотация: Вследствие переполнения орбит и дефицита частотных ресурсов, использование технологии МIMO для улучшения эффективности использования спектра и повышения пропускной способности канала становится обязательным трендом в системах широкополосной спутниковой связи. В данной статье проведен анализ основных факторов влияния и сравнивается коэффициент битовых ошибок BER (bit error rate) в системах пространственно-временного блочного кодирования STBC (space-time block code) и пространственно-временного решетчатого кодирования STTC (space-time trellis code). Предложена модель наземного канала мобильной спутниковой связи LMS (land mobile satellite) при различных условиях окружающей среды путем использования марковской цепи с тремя состояниями. В статье сделан акцент на изучении характеристики BER для схем кодирования STTC и STBC в случае спутникового канала со многими входами и многими выходами (MIMO). Основное внимание сосредоточено на влиянии таких факторов как окружающая среда терминала и углы возвышения на характеристику BER при использовании систем кодирования STBC и STTC. Результаты моделирования указывают на то, что эффективность схемы кодирования STTC в случае рэлеевского канала заметно улучшается с увеличением количества передающих и принимающих антенн, однако состояние кодера слабо влияет на эффективность системы. В случае рэлеевского канала, эффективность кода Аламоути выше, чем кода STTC. B LMS канале эффективность этих двух видов пространственно-временного кодирования на открытой местности является оптимальной, а в городской зоне - наихудшей. Тем не менее, эффективность схемы кодирования STTC немного превосходит эффективность схемы STBC при различных условиях. При одинаковых условиях окружающей среды значение BER схем кодирования STBC и STTC понижается при возрастании угла высоты спутника, и кривые BER для кода STTC спадают быстрее.
\end{abstract}

Ключевые слова: MIMO; пространственно-временной блочный код; STBC; пространственно-временной решетчатый код; STTC; наземный канал мобильной спутниковой связи; LMS канал; марковская цепь

\section{1. ВВЕДЕНИЕ}

Спутниковая связь обладает большим покрытием, широким частотным диапазоном и гибкостью. Эта связь способна обеспечить экс- тренные услуги при катастрофах и бедствиях в районах, где наземные средства связи разрушены землетрясением, цунами и военными действиями, в результате чего спутниковые

* $\quad$ Работа поддержана Фондом фундаментальных исследований для центральных университетов.

DOI: 10.20535/S0021347017010010

(С К. Джинг и Дж. Ву, 2017 


\section{БИБЛИОГРАФИЧЕСКИЙ СПИСОК}

1. Telatar I. E. Capacity of multi-antenna Gaussian channels / I. E. Telatar // European Trans. Telecom. 1999. - Vol. 10, No. 6. - P. 585-595. - DOI : 10.1002/ett.4460100604.

2. Loo C. A statistical model for a land mobile satellite link / Chun Loo // IEEE Trans. Vehicular Technol. Aug. 1985. - Vol. 34, No. 3. - P. 122-127. - DOI : 10.1109/T-VT.1985.24048.

3. Statistical modeling of the LMS channel / F. P. Fontan, M. Vazquez-Castro, C. E. Cabado, J. P. Garcia, E. Kubista // IEEE Trans. Vehicular Technol. - Nov. 2001. — Vol. 50, No. 6. - P. 1549-1567. — DOI : $10.1109 / 25.966585$.

4. From theory to practice: An overview of MIMO space-time coded wireless systems / David Gesbert, Mansoor Shafi, Da-shan Shiu, P. J. Smith, A. Naguib // IEEE J. Sel. Areas Commun. - Apr. 2003. - Vol. 21, No. 3. - P. 281-302. - DOI : 10.1109/JSAC.2003.809458.

5. Foschini G. J. Layered space-time architecture for wireless communication in fading environment when using multi-element antennas / Gerard J. Foschini // Bell Labs Tech. J. - 1996. - Vol. 1, No. 2. - P. 41-59. — DOI : $\frac{10.1002 / \mathrm{bltj} .2015 .}{6 .}$.

6. Yongzhao L. Improved BLAST for wireless communications / Li Yongzhao, Liao Guisheng, Wang Feng // J. Systems Engineering Electronics. - Mar. 2006. - Vol. 17, No. 1. - P. 48-53. - DOI : 10.1016/S1004-4132(06)60009-1.

7. Alamouti S. M. A simple transmit diversity technique for wireless communications / S. M. Alamouti // IEEE J. Sel. Areas Commun. — Oct. 1998. — Vol. 16, No. 8. - P. 1451-1458. - DOI : 10.1109/49.730453.

8. Tarokh $V$. Space-time block coding for wireless communications: performance results / V. Tarokh, H. Jafarkhani, A. R. Calderbank // IEEE J. Sel. Areas Commun. - Mar. 1999. - Vol. 17, No. 3. - P. 451-460. — DOI : $\underline{10.1109 / 49.753730 .}$.

9. Tarokh V. Space-time codes for high date rate wireless communication: Performance criterion and code construction / V. Tarokh, N. Seshadri, A. R. Calderbank // IEEE Trans. Inf. Theory. - Mar. 1998. - Vol. 44, No. 2. - P. 744-765. - DOI : 10.1109/18.661517.

10. Tolga $M$. Coding for MIMO Communication System / M. Tolga, Ali Ghrayeb. — England : John Wiley \& Sons Ltd, 2007.

11. $Y u X$. Power control scheme for multiple antenna systems with space-time coding in Rayleigh fading channels / Xiangbin Yu, Guangguo Bi // J. Systems Engineering Electronics. - Oct. 2011. - Vol. 22, No. 5. 
\begin{tabular}{cccc} 
P. & $730-738$. & DOI & : \\
\hline 10.3969/j.issn.1004-4132.2011.05.002. & &
\end{tabular}

12. King P. R. Characteristics of the land mobile satellite MIMO channel / Peter R. King, Stavros Stavrou // Vehicular Technology : IEEE Conf., 25-28 Sept. 2006, Montreal, Que : proc. - IEEE, 2006. - P. 1-4. - DOI : 10.1109/VTCF.2006.37.

13. MIMO-OFDM Wireless Communications with Matlab / Yong Soo Cho, Jaekwon Kim, Won Young Yang,
Chung G. Kang. - Singapore-England : John Wiley \& Sons Ltd, 2010.

14. Complex envelope three-state markov model based simulator for the narrow-band LMS channel / F. P. Fontán, J. P. González, M. J. S. Ferreiro, M. A. V. Castro, S. Buonomo, J. P. Baptista // Int. J. Satellite Commun. Networking. — Jan. 1997. — Vol. 15, No. 1. - P. 1-15. - $\quad$ DOI 10.1002/(SICI)1099-1247(199701)15:1<1::AID-SAT563 >3.0.CO;2-R.

Поступила в редакцию После переработки

\section{INFORMATION ON THE ARTICLE}

\section{PERFORMANCE COMPARISON OF SPACE-TIME BLOCK AND TRELLIS CODES IN THE MIMO LAND MOBILE SATELLITE CHANNELS ${ }^{* *}$}

Qingfeng Jing, jing_nuaa@163.com, Nanjing University of Aeronautics and Astronautics, China

Jiajia Wu, jjw090803@126.com, PANDA Electronics Group Co. Ltd., China

Due to the crowded orbits and shortage of frequency resources, the use of MIMO technology to improve spectrum efficiency and an increase of the capacity have become a necessary trend of broadband satellite communication. Firstly, we analyze the main influenced factors and compare the bit error rate (BER) performance of space-time block code (STBC) scheme and space-time trellis code (STTC) scheme. Then we build up the model of land mobile satellite (LMS) channel under different environments by using 3-state Markov chain. This paper emphatically studies the BER performance of STTC and STBC in the MIMO satellite channel. The main emphasis is placed on the effects of different factors, such as terminal environment and elevation angles, on the BER performance of STBC and STTC schemes. Simulation results indicate that performance of STTC in Rayleigh channel is obviously improved with the increasing number of transmitting and receiving antennas, but the encoder state has little impact on the performance. In the Rayleigh channel, the performance of Alamouti code is better than that of STTC. In the LMS channel, performance of these two kinds of space-time coding in open area is optimal, and in the urban area it is the worst. Nevertheless, performance of STTC is slightly superior to the performance of STBC under different circumstances. Under the same environmental conditions, BER of STBC and STTC reduces with the increase of the satellite altitude angle, and therefore, the BER curves of STTC fall faster.

Keywords: MIMO; space-time block code; STBC; space-time trellis code; STTC; land mobile satellite channel; LMS channel; Markov chain

** This work was supported by the National Science Foundation of China (61301105). 